10-18-1962

\title{
Leisure Time and Recreation
}

Wyatt Sawyer

Follow this and additional works at: https://scholarworks.harding.edu/wyatt-sawyer-sermons

\section{Recommended Citation}

Sawyer, W. (1962). Leisure Time and Recreation. Retrieved from https://scholarworks.harding.edu/wyattsawyer-sermons/504

This Sermon is brought to you for free and open access by the Wyatt Sawyer Archive at Scholar Works at Harding. It has been accepted for inclusion in Wyatt Sawyer Sermon Outlines by an authorized administrator of Scholar Works at Harding. For more information, please contact scholarworks@harding.edu.

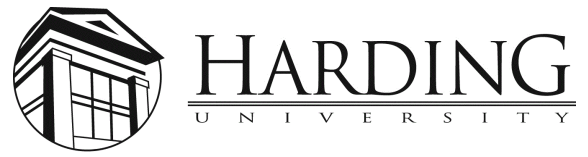


LETSURE TIME AND RECREATION

Ecc. $3: 1-8$

INT: Studying Christ's 2,000 year old answers to current prob. Lessons Two problems intrinsicly innerwoven.

I. A LOOK AT OUR CHUNGINO TORLD. CAUSE OP THE PROBLAH???

Telsure Time:

A. Agrarian Iife to Metropolitan way of Iffe. Farm to citj 1. Farm chores gone. Fer home duties. Stili"no time."

2. Wore gadgets inside and outside home. "Not enough TI

3. Shorter worlding weeks $32 \mathrm{hrs}$. of 168. shorter day:

6 hours work of 24. Shorter hour $245 \mathrm{~min}$. coffee!

4. Automoblie has revolutionlzed our living. Going, goi

5. Early retirement. $55 \mathrm{yrs} .62$ years. Leaves leisure

6. Location of domecil a factor.

a. III. Norweigan and toyless children. Houston.

B. Christ's answer to our growing lelsure. TAKE TIME TO BE

1. Contact the lost more. Mark 16:15-16.

HOLY

2. Read and study more. Finally some time! II T. 2:15.

3. Be benevolent. Hospitals, sick calls. M. 25836.0ldit,

4. Restore the erring. Gal. 6:1-2. Elders only! Nold

5. Back good community projects: Gal. 6:10. TAKS TINE TO BE HOLTHE:

II. SAME LENGTH OF TIME, IBSS WORK, EQUALS RECREATION!!! 168 hit. 48 to 70 luth $35,32,24.1 \mathrm{te}$.

A. What is Re-creation? Rest. Re-creating strength. Relax

B. How did Jesus relax and re-create? $m k .1: 35$, $\$ 10.5: 16,9,29$,

1. Iong prayer periods in mountains. Matt. $14: 22,0412$

2. Relaxed among friends and loved ones. Bethany. Jo 12

3. Played with children. Restful, invigorating.

III. Lubbock incident. Bryant children.

C. How are Americans re-creating today?

1. Drinking (escape), gambling (legal thieviry), dancing (80\% fallen girls started with this), petting (game of dynamite), speeding (American roulette), time coming up-maybe next time! BAPTIST TWIST.

D. Pressure on young Christians to mreck-create today. 1. Only the strongest w1Il withstand the pressure.E.232 III. CROKD can be wrong. Often is. See article.

E. Christ's answer to America!s Recreation Problem. 


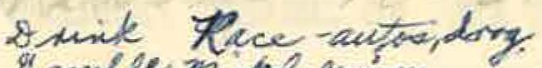

Hamble inipe-sinm,

Def sance

I. Iogical view: 11 good activities to each $I$ bad.

2. Scripturlal view: I Thesis. 5,21-22. desue gova fue are good for you, deny everything that would WHY? hurt you. II Tim. 3:I6-17. AND II TIm. 2:22. II1. WHAT HAPPENS TO BETHING BEAUTIES. Article.

4. Conmon sense view: TAKE TIME TO BE HOLY. I Timothy $4: 12-16$.

INV; Answer to whole problem is our attitude toward God. Matt. 22:37. Do nothing to hart His heart.

Do nothing to hurt His Son.

Do nothing to hurt His church.

Do nothing to hurt his prize- YOU.

Sinner: Acts 16:31-34.

Erring: Acts 8:22.

:Homeless: Place membership. 